\title{
Evaluation of Serum Vitamin D Levels according to Gender and Age at Karapınar City: A Follow-Up Study from Turkey
}

\author{
Saadet Kader ${ }^{a}$ Hakan Comaklı ${ }^{b}$ Mustafa Agah Tekindalc \\ a Biochemistry Laboratory Karapınar, Karapınar State Hospital, Konya, Turkey; ${ }^{b}$ Department of Cardiovascular \\ Surgery, Konya Training and Research Hospital, Konya, Turkey; ${ }^{C}$ Department of Biostatistics, Selçuk University \\ Faculty of Veterinary Medicine, Konya, Turkey
}

\section{Keywords}

Biochemistry · Gender · Laboratory · Medicine

\begin{abstract}
Aim: Vitamin D is one of the major hormones involved in phosphorus metabolism in the secosteroid structure. Studies have shown that low serum vitamin D levels are associated with chronic diseases such as autoimmune diseases, diabetes mellitus, chronic renal failure, depression, cardiovascular diseases, hypertension, and cancer. The aim of this study was to investigate serum vitamin D levels in the adult population according to age and gender in Karapınar, Turkey. Materials and Methods: Serum vitamin D levels of 6,774 patients admitted to Karapınar Public Hospital between January and December 2018 were evaluated according to age and gender, investigated, and retrospectively screened. Serum vitamin $D$ level $<10 \mathrm{ng} / \mathrm{mL}$ is accepted as deficiency, $10-30 \mathrm{ng} / \mathrm{mL}$ as insufficiency, $30-100 \mathrm{ng} / \mathrm{mL}$ as sufficiency, and $>100 \mathrm{ng} / \mathrm{mL}$ as toxicity. Results: The study consisted of 5,111 women $(75.5 \%)$ and 1,663 men (24\%). The mean vita$\mathrm{min} D$ levels were $14.6 \pm 0.2 \mathrm{ng} / \mathrm{mL}$ in women and $17.8 \pm 0.3$ $\mathrm{ng} / \mathrm{mL}$ in men. Vitamin $\mathrm{D}$ levels were found to be lower in both men and women as age progressed. Deficiency $(<10$ $\mathrm{ng} / \mathrm{mL}$ ) of vitamin $\mathrm{D}$ was found in $83.8 \%$ of women and
\end{abstract}

\begin{tabular}{ll}
\hline KARGER & ( 2019 The Author(s) \\
& Published by S. Karger AG, Basel \\
E-Mail karger@karger.com & This article is licensed under the Creative Commons Attribution- \\
www.karger.com/dmj & NonCommercial-NoDerivatives 4.0 International License (CC BY- \\
NC-ND) (http://www.karger.com/Services/OpenAccessLicense). \\
Usage and distribution for commercial purposes as well as any dis- \\
tribution of modified material requires written permission.
\end{tabular}

$18.2 \%$ of men, while insufficiency $(10-30 \mathrm{ng} / \mathrm{mL})$ of vitamin D was found in $69.6 \%$ of women and $30.4 \%$ of men. Conclusion: In this study, in patients who were admitted to our hospital in Karapınar City, serious vitamin D deficiency was detected. We recommend that people should take vitamin D and calcium supplements and they also should have more exposure to the sunlight.

(C) 2019 The Author(s)

Published by S. Karger AG, Basel

\section{Introduction}

Vitamin D is an important hormone for growth, development, and healthy skeletal structure that regulates calcium and phosphorus metabolism in the body. Vitamin D consists mainly of two forms: ergocalciferol (vitamin $\mathrm{D}_{2}$ ) and cholecalciferol (vitamin $\mathrm{D}_{3}$ ) caused by exposure to ultraviolet rays in the skin $[1,2]$. 90-95\% of the vitamin $\mathrm{D}$ in the human body is synthesized in the skin by the effect of sun rays, 25-hydroxyvitamin $\mathrm{D}(25(\mathrm{OH})$ $\mathrm{D})$, and 1,25-dihydroxyvitamin $\mathrm{D}(1,25(\mathrm{OH}) 2 \mathrm{D})$ with active forms undergoing hydroxylation in liver and kidney [3]. Rickets is developing because of inadequacy of mineralization of bone tissue. Absorption disorder, insufficient access to the sun, increased need for rapid growth,
Dr. Saadet Kader

Ulus Mh., D330 No:44, Clinical Biochemistry

Karapınar State Hospital 42400 Karapınar/Konya/Turkey

TR-530066 Konya (Turkey)

E-Mail saadetkader@hotmail.com 
Table 1. Distribution of patients by age and gender

\begin{tabular}{|c|c|c|c|c|c|c|}
\hline & & \multicolumn{2}{|c|}{ Gender } & & \multirow[t]{2}{*}{$\chi^{2}$} & \\
\hline & & male & female & & & \\
\hline \multicolumn{7}{|l|}{ Levels of vitamin D } \\
\hline \multirow[t]{2}{*}{$0-10$, deficiency } & $n$ & $464^{\mathrm{a}}$ & $2,393^{\mathrm{b}}$ & 2,857 & 200.392 & 0.001 \\
\hline & $\%$ & $16.2 \%$ & $83.8 \%$ & $100.0 \%$ & & \\
\hline \multirow[t]{2}{*}{$11-30$, insufficiency } & $n$ & $1,006^{\mathrm{a}}$ & $2,298^{\mathrm{b}}$ & 3,304 & & \\
\hline & $\%$ & $30.4 \%$ & $69.6 \%$ & $100.0 \%$ & & \\
\hline \multirow[t]{2}{*}{ 31-100, optimal level } & $n$ & $137^{\mathrm{a}}$ & $232^{\mathrm{b}}$ & 369 & & \\
\hline & $\%$ & $37.1 \%$ & $62.9 \%$ & $100.0 \%$ & & \\
\hline \multirow[t]{2}{*}{$101+$, toxicity } & $n$ & $56^{\mathrm{a}}$ & $188^{\mathrm{a}}$ & 244 & & \\
\hline & $\%$ & $23.0 \%$ & $77.0 \%$ & $100.0 \%$ & & \\
\hline \multirow[t]{2}{*}{ Total } & $n$ & 1,663 & 5,111 & 6,774 & & \\
\hline & $\%$ & $24.5 \%$ & $75.5 \%$ & $100.0 \%$ & & \\
\hline
\end{tabular}

25(OH)D total: deficiency, $<10$; insufficiency, 10-30; sufficiency, 30-100; toxicity, $>100$. $^{\text {a }} 0$ cells $(0.0 \%)$ have expected count less than 5 . The minimum expected count is $59.90 .{ }^{\mathrm{b}}$ Based on 10,000 sampled tables with starting seed 957002199.

and lack of intake of vitamin D contributes to the formation of rickets. Vitamin D deficiency has been reported to play a role in the formation of many diseases, except for the effects of bone tissue.

Serum 25(OH)D levels are considered to reflect vitamin D status $[4,5]$. Recently, the term 25 vitamin D deficiency 25 was used to describe low serum $25(\mathrm{OH}) \mathrm{D}$ status [6]. Levels above $30 \mathrm{ng} / \mathrm{mL}$ ( $75 \mathrm{nmol} / \mathrm{L})$, between 10 and $30 \mathrm{ng} / \mathrm{mL}(50-75 \mathrm{nmol} / \mathrm{L})$, and below $10 \mathrm{ng} / \mathrm{mL}(50$ $\mathrm{nmol} / \mathrm{L}$ ) are considered to be sufficient, inadequate, and deficient, respectively [7]. Since the half-life is long, it reflects the vitamin D which is both synthesized in the skin and the dietary vitamin $\mathrm{D}$ and shows the depot status in the body [8-10]. The data about the vitamin D status in the literature do not include our country's vitamin D test results. Due to the physical differences of the human race and the environmental factors, some country-based or even regional metabolic values may vary among individuals. Karapinar is a city of Konya. Konya is located in Turkey's Anatolian interior. It can be thought that vitamin D deficiency will not be seen because it is in an area with plenty of sun. But we have seen that a lot of patients who suffered vitamin D deficiency. The purpose of our study was to investigate serum $25(\mathrm{OH}) \mathrm{D}$ levels in the adult population (10-91) according to age and gender in Karapınar City, Turkey.

\section{Materials and Methods}

The medical records of the patients who were admitted to Karapinar State Hospital between January 2018 and December 2018 were retrospectively screened and the patient medications were evaluated. Patients with celiac disease, chronic liver disease, stage 3, 4, 5 chronic kidney disease, vitamin D replacement therapy, and autoimmune diseases were excluded from this study. Serum vitamin D levels of 6,774 patients were retrospectively screened according to age and gender. Serum 25(OH)D level $<10$ $\mathrm{ng} / \mathrm{mL}$ is accepted as deficiency, $10-30 \mathrm{ng} / \mathrm{mL}$ as insufficiency, 30 $40 \mathrm{ng} / \mathrm{mL}$ as sufficiency, and $>100 \mathrm{ng} / \mathrm{mL}$ as toxicity. Serum levels of vitamin D were determined by the chemiluminescence method on Siemens Advia Centaur Classic (Siemens Healthcare Diagnostics, Tarrytown, NY, USA) using the kit (Lot 54482110) (4.2-150 $\mathrm{ng} / \mathrm{mL}$ ) of the same company.

\section{Statistical Analysis}

The statistical analysis was performed using IBM SPSS Statistics version 21.0 software (IBM Corp., Armonk, NY, USA). Comparisons of demographic and clinical parameters of the two groups were performed using the Chi-square test, Student $t$ test (independent samples $t$ test), or Mann-Whitney $\mathrm{U}$ test, as appropriate; the Kruskal-Wallis test was used for the comparison of more than two groups. All $p$ values of less than 0.05 based on a two-tailed test were considered statistically significant. 
Fig. 1. Vitamin D levels according to age.

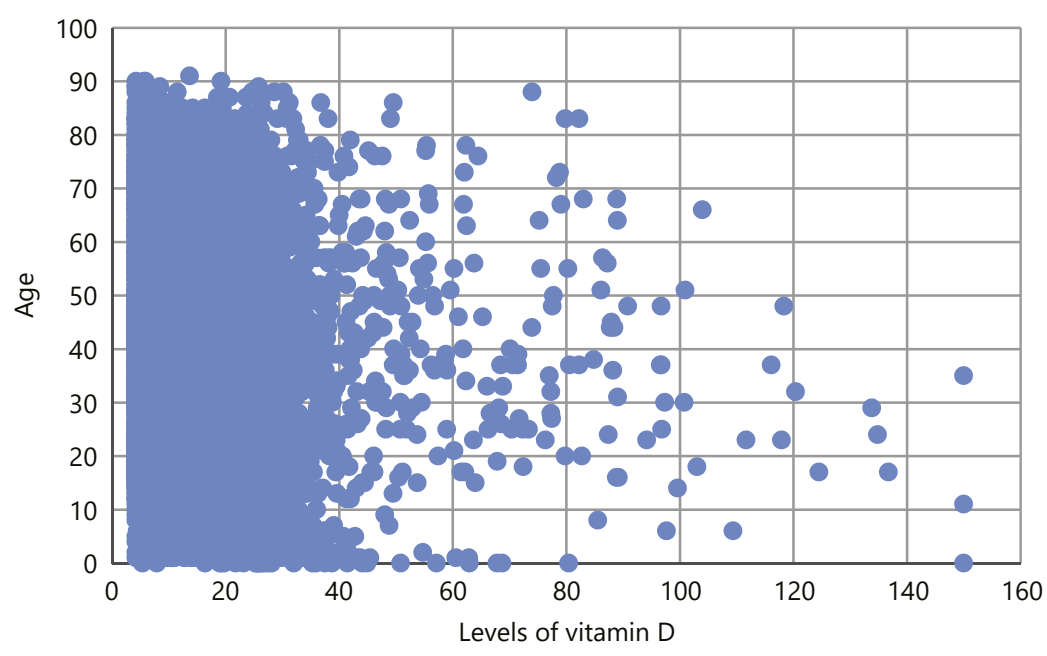

\section{Results}

A total of 6,774 patients were evaluated for vitamin $D$ levels in Karapinar City in 2018. Of these patients, 5,111 (75.5\%) were women and 1,663 (24\%) were men. In all patients, the $25(\mathrm{OH}) \mathrm{D}$ averaged over the year was $14.6 \pm$ $0.2 \mathrm{ng} / \mathrm{mL}$ in women and $17.8 \pm 0.3 \mathrm{in}$ men. The distribution of patients by age and gender is shown in Table 1. When the patient results were evaluated as percentage, $83.8 \%$ of women and $18.2 \%$ of men were below the values defined for severe vitamin $\mathrm{D}$ deficiency $(<10 \mathrm{ng} / \mathrm{mL})$. Insufficiency in vitamin D (10-30 ng/mL) was found in $69.6 \%$ of women and $30.4 \%$ of men. The optimal level of vitamin D level of $30-100 \mathrm{ng} / \mathrm{mL}$ was found in $62.9 \%$ of women and $37.1 \%$ of men. The toxic level of vitamin $\mathrm{D}$ level (>100 ng/mL) was found in $77 \%$ of women and $23 \%$ of men. The distribution of patients according to vitamin $\mathrm{D}$ levels is given in Table 2. The differences between genders were significant in vitamin D levels $(p<0.05)$. Vitamin $\mathrm{D}$ levels show a significant decrease as age increases (Fig. 1; Table 3).

\section{Discussion}

Vitamin D is important for normal development and protection of bone. Vitamin D deficiency has negative effects on calcium metabolism, osteoblastic activity, matrix ossification, bone remodeling, and bone density [11]. Vitamin $\mathrm{D}$ deficiency is a common condition associated
Table 2. Distribution of patients by age and gender

\begin{tabular}{lllllll}
\hline Gender & $N$ & $\bar{x}$ & $\begin{array}{l}\text { Std. } \\
\text { deviation }\end{array}$ & Median & Min. & Max. \\
\hline Male & 1,663 & 17.81 & 12.70 & 15.01 & 4.20 & 150.00 \\
Female & 5,111 & 14.66 & 13.10 & 10.67 & 4.20 & 150.00 \\
\hline Total & 6,774 & 15.43 & 13.07 & 11.71 & 4.20 & 150.00 \\
\hline
\end{tabular}

Table 3. Correlation of vitamin $\mathrm{D}$ according to age

\begin{tabular}{llc}
\hline & & Vitamin D \\
\hline Age & $\rho$ & $-0.114^{* *}$ \\
& $p$ & 0.001 \\
& $n$ & 6,790
\end{tabular}

** $\rho$ : Spearman's rank correlation coefficient. $n$, total number of patients.

with many diseases including osteoporosis in the elderly, rickets in children, some cancers, cardiovascular diseases, and diabetes mellitus $[12,13]$. There is no consensus on the optimal serum $25(\mathrm{OH}) \mathrm{D}$ levels for bone health. The American Institute of Medicine (IOM) and American Geriatric Society recommend that serum 25(OH)D levels should be above $20 \mathrm{ng} / \mathrm{mL}$ and $30 \mathrm{ng} / \mathrm{mL}$, respectively, to minimize the risk of falls and fractures [14-18]. 
Although there is no wide-ranging study to determine vitamin D levels in our country, due to the reduced risk of falls and the benefits associated with metabolic diseases. The Osteoporosis and Metabolic Bone Diseases Working Group of the Turkey Endocrinology and Metabolism Society defined serum $25(\mathrm{OH}) \mathrm{D}$ levels above $30 \mathrm{ng} / \mathrm{mL}$ of vitamin D as optimal, levels between $20-30 \mathrm{ng} / \mathrm{mL}$ as insufficiency, $<20 \mathrm{ng} / \mathrm{mL}$ vitamin $\mathrm{D}$ as deficiency, and $<10$ $\mathrm{ng} / \mathrm{mL}$ as severe deficiency. It is estimated that approximately one billion people in the world suffer from vitamin $\mathrm{D}$ deficiency [19]. In the literature, vitamin D status differs in several countries, even in various regions of the same country. In America and Europe, vitamin D deficiency was reported to be found in $40-100 \%$ of elderly men and women living in a community [19]. Prevalence of vitamin D deficiency is also much higher in Asia. A total of 30-50\% of people in India, Lebanon, and Turkey [20] and also $45.2 \%$ of women in China [20] were vitamin D deficient. Studies have shown that especially in $25(\mathrm{OH}) \mathrm{D}$, levels were $<75 \mathrm{nmol} / \mathrm{L}(<30 \mathrm{ng} / \mathrm{mL})$ in the black race and elderly people in Canada. Approximate 25(OH)D levels in winter and spring seasons have been shown to be $<50 \mathrm{nmol} / \mathrm{L}$ ( $<20 \mathrm{ng} /$ $\mathrm{mL}$ ), with seasonal variation between 60 and 120\% [21].

Several studies in different parts of Turkey and among different age groups have shown a high prevalence of vitamin $\mathrm{D}$ deficiency [23-26]. Uçar et al. [27] found that the mean 25(OH)D levels of 513 patients were lower than 30 $\mathrm{ng} / \mathrm{mL}$, and when they were taken as $20 \mathrm{ng} / \mathrm{mL}$ cut-off, $51.8 \%$ vitamin $\mathrm{D}$ deficiency and $20.7 \%$ vitamin D deficiency were detected in the patients. In a study by Ögüss and his friends [28], serum vitamin $\mathrm{D}$ levels of the patients were found to be $22.8 \pm 13.3 \mathrm{ng} / \mathrm{mL}$. According to their study's results, they found vitamin D levels of $<20$ $\mathrm{ng} / \mathrm{mL}$ in $47 \%$ of patients $(50 \%$ of women and $38 \%$ of men). We also found that vitamin $\mathrm{D}$ levels were significantly lower in women than in men. In our study, our results were expressed as percentage: $83.8 \%$ of women and $18.2 \%$ of men were below the values defined for severe vitamin $\mathrm{D}$ deficiency $(<10 \mathrm{ng} / \mathrm{mL})$. As for vitamin $\mathrm{D}$ insufficiency $(10-30 \mathrm{ng} / \mathrm{mL})$, these values were found in $69.6 \%$ of women and $30.4 \%$ of men. The main cause of vitamin D deficiency can be attributed to lack of sun exposure [29]. Although our country is located in a geographic region which is sun-drenched throughout the year, it can be seen with low vitamin D levels in which the sun cannot be used sufficiently. There may be different reasons. The majority of our people are unable to benefit from the sun because of their religious beliefs.

Besides these reasons, different cut-off values in the studies and discrepancy between the measurement meth- ods (tandem-mass spectrometry, radioimmunoassay, and automated immunoassay systems) should be taken into consideration and further standardization studies should be performed for vitamin D. Gender and age influence serum 25(OH)D levels. Differences according to gender and age group may be because of biological differences but might also be due to behavioral differences. There might be gender-specific clothing differences (necessarily not based on a religious culture). There also might be that women spend less time outside, resulting in less exposure to the sun [30]. In a study by Andersen et al. [31], serum vitamin D levels decreased during military training in the summer due to the type of clothing worn during training, coupled with inadequate vitamin $\mathrm{D}$ intake among the woman soldiers in the United States.

Our study found that vitamin D deficiency was also associated with age, and most studies found higher prevalence of vitamin D deficiency among the elderly [32-34], probably due to lower capacity of the skin to produce vitamin D after sun exposure [33] or less vitamin D intake in the elderly [33], although a few studies reported higher prevalence of vitamin D deficiency in young people [34].

\section{Conclusion}

Our study determined serum vitamin D levels according to age and gender in a local population. Most of the patients were found to be vitamin $\mathrm{D}$ deficient. There were significantly lower serum vitamin D levels in women compared to men and our study found a higher prevalence of vitamin D deficiency among elderly people. Evaluation of serum vitamin D levels with other risk factors and bone metabolism is of great importance.

\section{Study Limitations}

Since the study is retrospective, patients who get vitamin $\mathrm{D}$ are unknown and the degree of exposure to sun is also unknown. Most of the patients included in this study were women. The absolute majority of the participants were from Karapinar City, but more detailed information about skin type or color was not obtained. In addition, we did not have the opportunity to include patients who have applied to our primary health care services and follow patients afterwards. As a result, the study may not be representative of the general population who are from Karapinar City.

\section{Acknowledgement}

We thank the anonymous referees for their useful suggestions. 


\section{Statement of Ethics}

The work described in this article has been carried out in accordance with the Code of Ethics of the World Medical Association (Declaration of Helsinki) for experiments involving humans and uniform requirements for manuscripts submitted to biomedical journals.

\section{Disclosure Statement}

The authors have no potential conflicts of interest to disclose.

\section{Funding Sources}

During this study, no financial or spiritual support was received neither from any pharmaceutical company that has a direct connection with the research subject, nor from a company that provides or produces medical instruments and materials, which may negatively affect the evaluation process of this study.

\section{Author Contributions}

Conception, design: S.K. Writing, revision: all authors. Final approval: all authors.

\section{References}

1 Ataş A, Çakmak A, Soran M. D vitamini metabolizması ve Rikets hastalığı. Bakırköy Tip Dergisi. 2008;4:1-7.

2 Kulie T, Groff A, Redmer J, Hounshell J, Schrager S. Vitamin D: an evidence-based review. J Am Board Fam Med. 2009 Nov-Dec; 22(6):698-706

3 Shoback D, Sellmeyer D, Bikle DD. Metabolik kemik hastalıkları. In: Gardner DG, Shoback D, editors. Greenspan's Temel ve Klinik Endokrinoloji (Çeviri). 8. Baskı. Ankara: Güneş Tip Kitabevleri; 2009. pp. 281-345.

4 Abrams SA. Nutritional rickets: an old disease returns. Nutr Rev. 2002 Apr;60(4):111-5.

5 Hollick MF. Sunlight and vitamin D for bone health and prevention of autoimmune diseases, cancer and cardiovascular disease. Am J Clin Nutr. 2004;80(6):1678-88.

6 Thacher TD, Clarke BL. Vitamin D insufficiency. Mayo Clin Proc. 2011 Jan;86(1):50-60.

7 Holick MF. Vitamin D: important for prevention of osteoporosis, cardiovascular heart disease, type 1 diabetes, autoimmune diseases, and some cancers. South Med J. 2005 Oct; 98(10):1024-7.

8 Canadian Agency for Drugs and Technologies in Health. Vitamin D Testing in the General Population: A Review of the Clinical and Cost-Effectiveness and Guidelines. Ottawa (ON); 2015

9 Christodoulou S, Goula T, Ververidis A, Drosos G. Vitamin D and bone disease. BioMed Res Int. 2013;2013:396541.

10 Halicioglu O, Aksit S, Koc F, Akman SA, Albudak E, Yaprak I, et al. Vitamin D deficiency in pregnant women and their neonates in spring time in western Turkey. Paediatr Perinat Epidemiol. 2012 Jan;26(1):53-60.

11 Christodoulou S, Goula T, Ververidis A, Drosos G. Vitamin D and bone disease. BioMed Res Int. 2013;2013:396541.

12 Kumar GT, Chugh R, Eggersdorfer M. Poor vitamin $\mathrm{D}$ status in healthy population in India: a review of current evidence. Int J Vitam Nutr Res. 2015;85:1-7.

13 Atalay SG, Atalay R, Alkan BM, et al. Vitamin $\mathrm{D}$ deficiency in adults with musculoskeletal pain. Turk J Osteoporos. 2015;21(3):101-4.
14 Ross AC, Manson JE, Abrams SA, Aloia JF, Brannon PM, Clinton SK, et al. The 2011 report on dietary reference intakes for calcium and vitamin $\mathrm{D}$ from the Institute of Medicine: what clinicians need to know. J Clin Endocrinol Metab. 2011 Jan;96(1):53-8.

15 Holick MF, Binkley NC, Bischoff-Ferrari HA, Gordon CM, Hanley DA, Heaney RP, et al.; Endocrine Society. Evaluation, treatment, and prevention of vitamin D deficiency: an Endocrine Society clinical practice guideline. J Clin Endocrinol Metab. 2011 Jul;96(7): 1911-30.

16 Vieth $\mathrm{R}$. What is the optimal vitamin D status for health? Prog Biophys Mol Biol. 2006 Sep; 92(1):26-32.

17 Dawson-Hughes B, Mithal A, Bonjour JP Boonen S, Burckhardt P, Fuleihan GE, et al. IOF position statement: vitamin $\mathrm{D}$ recommendations for older adults. Osteoporos Int. 2010 Jul;21(7):1151-4.

18 American Geriatrics Society Workgroup on Vitamin D Supplementation for Older Adults. Recommendations abstracted from the American Geriatrics Society Consensus Statement on vitamin D for Prevention of Falls and Their Consequences. J Am Geriatr Soc. 2014 Jan;62(1):147-52.

19 Levels in the adult population living in Bilecik Province: A Follow-up Study from Turkey. Md Med J. 2018;33(4):296-9.

20 Holick MF. Vitamin D deficiency [Pub Med]. N Engl J Med. 2007 Jul;357(3):266-81.

21 Vuistiner P, Rousson V, Henry H, Lescuyer P, Boulat O, Gaspoz JM, et al. A populationbased model to consider the effect of seasonal variation on serum $25(\mathrm{OH}) \mathrm{D}$ and vitamin $\mathrm{D}$ status. BioMed Res Int. 2015;2015:168189.

22 Du X, Greenfield H, Fraser DR, Ge K, Trube A, Wang Y. Vitamin D deficiency and associated factors in adolescent girls in Beijing [PubMed]. Am J Clin Nutr. 2001 Oct;74(4): 494-500.

23 Alagöl F, Shihadeh Y, Boztepe H, Tanakol R, Yarman S, Azizlerli H, et al. Sunlight exposure and vitamin D deficiency in Turkish women. J Endocrinol Invest. 2000 Mar;23(3):173-7.
24 Atli T, Gullu S, Uysal AR, Erdoğan G. The prevalence of Vitamin D deficiency and effects of ultraviolet light on Vitamin D levels in elderly Turkish population. Arch Gerontol Geriatr. 2005 Jan-Feb;40(1):53-60.

25 Hekimsoy Z, Dinç G, Kafesçiler S, Onur E, Güvenç Y, Pala T, et al. Vitamin D status among adults in the Aegean region of Turkey. BMC Public Health. 2010 Dec;10(1):782.

26 Cigerli O, Parildar H, Unal AD, Tarcin O, Erdal R, Guvener Demirag N. Vitamin D deficiency is a problem for adult out-patients? A university hospital sample in Istanbul, Turkey. Public Health Nutr. 2013 Jul;16(7):1306-13

27 Uçar F, Yavuz Taşlıpınar M, Özden Soydaş A, Özcan N. Ankara Etlik İhtisas Eğitim ve Araştırma Hastanesine başvuran hastalarda 25-OH Vitamin D düzeyleri. Eur J Basic Med Sci. 2012;2:12-5.

28 Öğüş E, Sürer H, Kilınç A, Fidancı V, Yılmaz G, Dindar N, et al. (2014). Evaluation of Vitamin D Levels by Months, Sex and Age. Ankara Med J. 2015;15:1-5.

29 Sözen T. D hormonu: güncel gelișmeler. Hacettepe Tip Dergisi. 2011;42:14-27.

30 Hashemipour S, Larijani B, Adibi H, Javadi E, Sedaghat M, Pajouhi M, et al. Vitamin D deficiency and causative factors in population of Tehran. BMC Public Health. 2004;4:1-6.

31 Andersen N, Karl J, Cable S, Williams K, Rood J, Y oung A, et al. V itamin D status in woman military personnel during combat training. J Int Soc Sports Nutr. 2010;7:1-5.

32 Burnand B, Sloutskis D, Gianoli F, Cornuz J, Rickenbach M, Paccaud F, et al. Serum 25-hydroxyvitamin D: distribution and determinants in the Swiss population [PubMed]. Am J Clin Nutr. 1992 Sep;56(3):537-42.

33 Omdahl JL, Garry PJ, Hunsaker LA, Hunt WC, Goodwin JS. Nutritional status in a healthy elderly population: vitamin D [PubMed]. Am J Clin Nutr. 1982 Dec;36(6): 1225-33.

34 Hovsepian S, Amini M, Aminorroaya A, Amini P, Iraj B. Prevalence of vitamin D deficiency among adult population of Isfahan City, Iran [PMC free article] [PubMed]. J Health Popul Nutr. 2011 Apr;29(2):149-55. 